\title{
THE CATOPINAE (COLEOPTERA; LEIODIDAE) OF PUERTO RICO*
}

\author{
By Stewart B. Peck \\ Museum Comparative Zoology, Harvard University \\ Cambridge, Massachusetts 02138
}

Only three species of Catopinae have been reported from the Greater Antillean Islands: Dissochaetus portoricensis Hatch 1933 from Puerto Rico; Ptomaphagus (Adelops) darlingtoni Jeannel I936 from Cuba; and Proptomaphaginus apodemus Szymczakowski 1969 from Cuba. These three species are known from a total of four specimens.

In December-January 1966-I967 I had the opportunity to collect in Puerto Rico and to begin field studies on the evolution and distribution of West Indian Leiodidae. This paper reports on the Puerto Rican collections. Seventeen days were spent in the field. Twelve collecting visits were made to I I caves along the north slope of the island. Carrion (rotted liver) and yeast baited pitfall traps were set in the moist forests of the eastern and central parts of the Island. The collecting stations yielding Catopinae are shown in fig. I. Collected were 230 Dissochaetus portoricensis and 60 specimens of a new species of Proptomaphaginus. Additional information is given for Cuban Proptomaphaginus.

\section{Dissochaetus portoricensis Hatch 1933}

Fig. 9

Type: I female, El Yunque, Puerto Rico, alt. 2950', Feb. 1900, L. Stejneger leg., in U. S. National Museum. I have seen the type.

Up to now the species was known only from the single type female. The collection of several males allows additional description.

Males. Total length 2.1-2.3 mm., noticeably smaller than females (total length 2.6-2.8 mm.). Aedeagus elongate, narrowing gradually to tip, small notch at tip. Parameres long and thin, slightly reaching beyond tip of aedeagus, armed with two apical hairs. Both narrow and straight in side view. Internal sac with two thin chitinized pieces. Ligulae lacking.

Zoogeography. The species seems to belong to the spinipes group

*Manuscript received by the editor, May 6, 1970. 
of Jeannel (1936) which mostly inhabits South America. The two known Lesser Antillean Dissochaetus (granadensis Jeannel 1936 of Granada and smithi Jeannel 1936 of St. Vincent) are in this group, and suggest initial colonization of Puerto Rico either directly from South America or indirectly by way of the Lesser Antilles. However, the possibility cannot be excluded of the beetles having reached Puerto Rico either directly or by way of other Greater Antillean Islands from Central America or Mexico. The Dissochaetus of these later three groups are yet too poorly known to evaluate the faunal relationships.

Collections. Puerto Rico. Luquillo Experimental Forest, (El Yunque area), 26.xii.r966-i.i.I967, S. Peck, carrion trap, I male, I female. Toro Negro Forest, Cerro Dona Juana, 28.xii.I966-4.i. 1967, S. Peck, rooom, yeast bait trap, i6 females; carrion bait trap, I male, 23 females; carrion bait traps, 900m, Io males, I70 females; carrion bait trap, $600 \mathrm{~m}, 3$ males, 5 females.
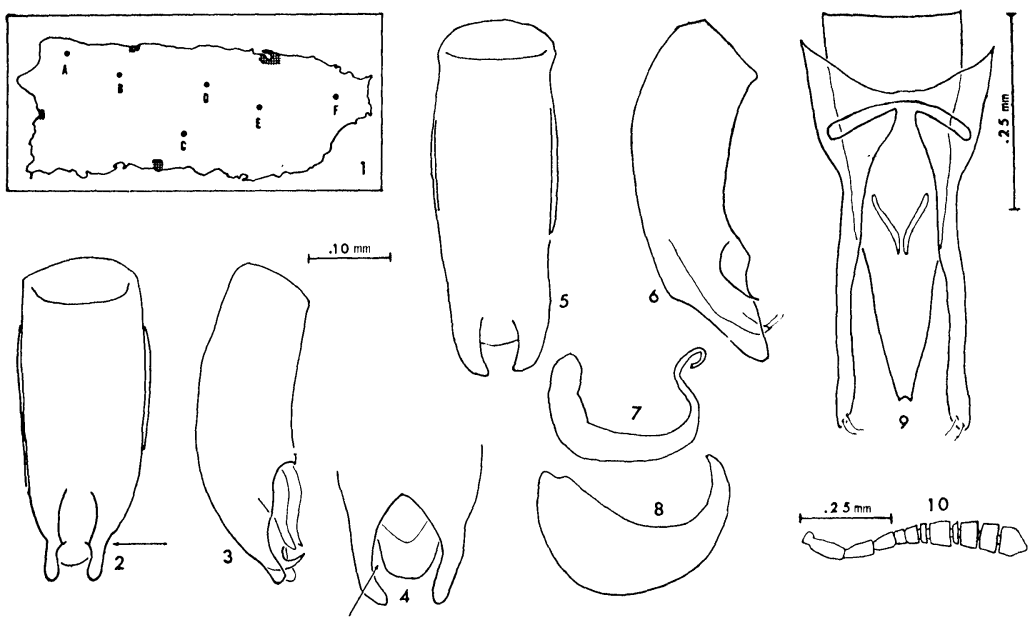

Figures 1-10. Fig. 1, collecting sites on Puerto Rico yielding Catopinae. (A). Cueva de los Alfaros. (B). Empalme Cave. (C). Toro Negro Forest. (D). Cueva de Corozal. (E). Aguas Buenas Cave. (F). Luquillo Forest, (El Yunque). Fig. 2, dorsal surface aedeagus Proptomaphaginus darlingtoni. Fig. 3, lateral surface aedeagus P. darl.ngtoni. Fig. 4, dorsal surface of tip of aedeagus $P$. apodemus. Fig. 5, dorsal surface aedeagus $P$. puertoricensis, Fig. 6, lateral surface aedeagus $P$. puertoricensis. Fig. 7, spermatheca of $P$. puertoricensis. Fig. 8, spermatheca of $P$. apodemus. Fig. 9, dorsal surface aedeagus Dissochaetus portoricensis. Fig. 10, antenna $P$. puertoricensis. 
Ecology. The species is appreciably more abundant in the less wet forests of the Island's center. Two hundred and twenty eight specimens were collected in five traps in the moist Toro Negro forests of the center of the Island, while only two specimens were collected in 9 traps in the wet eastern montane Luquillo forest.

Genus Proptomaphaginus Szymczakowski

Diagnosis. Mesothoracic episternum not reaching coxal cavity. Metathoracic epimeron clearly transverse. Male portarsi not expanded. Flattened protibia with row of short equal spines along outer margin. Bilobed aedeagal apex, orifice central on ventral surface.

Zoogeography. The genus is most closely related to Ptomaphaginus (with 23 species limited to the Indo-Malayan region). When Szymczakowski (1969) described Proptomaphaginus and the Cuban species apodemus he pointed out the possible ancient significance of this disjunct distributional relationship. His views are not weakened by the addition of the following Puerto Rican species and the following transfer of Ptomaphagus (Adelops) darlingtoni to this genus.

Additional evidence is now available on the source of the original West Indian colonization of Proptomaphaginus or its ancestor. The genus occurs on the island of Hispaniola (I have seen one female of a possibly undescribed species in the MCZ collections). I did not find it in two weeks of field work in Jamaica in 1968. The genus occurs in Mexico ( $\mathrm{I}$ found an undescribed edaphobitic species in a cave in the Mexican state of San Luis Potosi in 1969). It has not been found in Central America. I found none in field work in 1965 in Panama and Costa Rica or in 1969 in Guatemala, and none are in Dybas' extensive 1959 Panama collections in the Field Museum. This pattern of occurrence on three Greater Antillean Islands and in Mexico and absence from Jamaica and Central America suggests initial derivation from Mexican lands, and not Central American lands by way of Jamaica.

\section{Proptomaphaginus puertoricensis new species}

Figs. 5-7, 10

Holotype. Male (deposited in Museum Comparative Zoology, Harvard University, MCZ type \#31886). Puerto Rico; Torro Negro Forest, Cerro Dona Juana, 28.xii.1966-4.i.1967, S. Peck, carrion trap, $900 \mathrm{~m}$ elev. Female allotype and 6 paratypes, same data. 
Diagnosis. Very similar to $P$. apodemus and $P$. darlingtoni of Cuba in external appearance. Differing mostly in shape of internal male and female genital structures. The male aedeagus of puertoricensis when seen in lateral view has higher and broader lateral extensions at its posterior (fig. 6), than darlingtoni (fig. 3) and apodemus. The aedeagus of puertoricensis in dorsal view is wider and shows more regularity in the external outer surfaces at its posterior (fig. 5) than in darlingtoni (fig. 2) or apodemus (fig. 4). The female spermatheca of puertoricensis is more slender (fig. 7) than apodemus (fig. 8).

Description of holotype. Length $1.70 \mathrm{~mm}$, width $0.85 \mathrm{~mm}$. Color reddish brown. Shape elongate oval, convex. Pubescence short and thick. Head width $0.55 \mathrm{~mm}$. Eyes large, anterio-posterior diameter 4 times wider than distance between eye and antennal insertion.

Antennal club flattened, segments as in fig. Io.

Pronotum convex, width $0.83 \mathrm{~mm}$, length $0.48 \mathrm{~mm}$, widest at point $3 / 4$ along length, posterior margin even. Distinct transverse striae. Hind margin slightly sinuous, hind angles drawn out.

Elytral length $1.20 \mathrm{~mm}$, width $0.85 \mathrm{~mm}$. Narrowing at front, sides slightly curved; apex truncate, slightly concave; sutural angle rounded. Striae distinct, oblique.

Fully developed flight wings.

Mesosternal carina low.

Aedeagus tubular, broad, straight, with ventral orifice, bilobed lateral projections at apex.

Female paratype like male holotype, with thin, curved, spermatheca.

Collections. Puerto Rico: Cueva de los Alfaros, Barrio Mora, near Isabela, 4 July 1958, M. W. Sanderson, IOO on bat guano (Illinois Natural History Survey collection). Empalme Cave, Bayaney, near Arecibo, 7.i.1967, S. Peck, 15. Cueva de Corozal, Corozal, 6.i.I967, S. Peck, 5 in cave carrion trap. Aguas Buenas Cave, Aguas Buenas, 30.xii.rg66, S. Peck, 26 on fruit bat guano. Aguas Buenas Cave, river passage, I3 Feb., I968, B. Fenton, IO on dead bat (in Canadian National Collection, Ottawa). Toro Negro Forest, Cerro Dona Juana, carrion baited pitfall traps, 28.xii.19664.i.1967, S. Peck, $600 \mathrm{~m}$. elev., 2; $900 \mathrm{~m}, 8$; $1000 \mathrm{~m}, 2$; yeast baited pitfall trap, $900 \mathrm{~m}$, I. Luquillo Experimental Forest, carrion pitfall traps, 26.xii.1966-1.i.1967, S. Peck, $300 \mathrm{~m}, 2$; $500 \mathrm{~m}$, 
I. El Yunque and vicinity, I6-I7 July 1958, M. W. Sanderson, beating and sweeping, I (Illinois Natural History Survey collection).

Ecology. Most of the cave collections were from bat guano, found in association with their larvae, and not far from the cave entrance. It would seem that the lowland cave populations may now be at least partially isolated from the montane forest populations since the clearing and destruction of much of the lowland forest for agricultural purposes. I visited Cueva de los Alfaros where Sanderson found the beetles abundant, and found none. The Cerro Dona Juana forest collections were from traps in moist closed-canopy forest with a good ground cover of herbaceous plants. Floor litter was abundant at higher elevations. The beetles are more abundant in the Cerro Dona Juana forest. Four carrion and one yeast baited trap in the Cerro Dona Juana forest caught I 3 beetles, compared with 3 beetles from 6 carrion and 3 yeast traps in the Luquillo forest. A possible explanation for the lower catch in the montane Luquillo rain forest is that it may be too wet.

Proptomaphaginus darlingtoni (Jeannel), new combination Figs. 2, 3 .

Ptomaphagus (Adelops) darlingtoni Jeannel 1936: 92.

Type: I male (MCZ number 2252I). Cuba, Cienfuegos, Soledad, x.28.1926, Darlington. "Wash. gravel bar small brook in woods".

Examination and dissection of the type show it to be a male (not a female as Jeannel stated, because of the narrow pro-tarsomeres, a female character in other Catopinae), and to have an aedeagus very similar to $P$. apodemus.

The similarity of the two species is very striking. The only available characters to separate them are the smaller size of darlingtoni ( $1.6 \mathrm{~mm}$ ) compared to apodemus $(2.0-2.2 \mathrm{~mm})$, and a few minor details of the aedeagus. The aedeagus of darlingtoni is smaller and has a greater constriction at the base of the lateral lobes (arrow in fig. 2), than apodemus (fig. 4), the aedeagus tip is broad in darlingtoni between the lateral lobes and narrow in apodemus so that a space shows along the lobes in their interior side (arrow in fig. 4).

There is a possibility that darlingtoni and apodemus are conspecific. Only further collecting will show if the differences are distinct between populations, or only extremes of variation within populations. The two localities are $130 \mathrm{~km}$ from each other, and on opposite sides of the Island. 
I believe the species is still known only from the type. I discount the records of Jeannel and Henrot (1949: 98) of the species from San Jose and Reventazon in Costa Rica. These specimens must be reexamined. Their identity will influence future zoogeographic conclusions.

\section{Proptomaphaginus apodemus Szymczakowski Fig. 8}

Described from two males from Humbolt Cave, Punta Caguanes, Las Villas Province, Cuba. Through the kindness of Ing. Fernando de Zayas, Academy of Sciences, Havana, Cuba, I have had the opportunity to examine two additional males and two females.

The female specimens allow me to illustrate the female spermatheca (fig. 8) and compare it to that of $P$. puertoricensis. In apodemus it is swollen at one end, and gradually curves and constricts to a point at the other end. The spermatheca of darlingtoni is unknown.

The specimens came from "Cueva Caguanes", May 1958, F. de. Zayas collector. They are either from the type cave populations, or from another cave very near by.

\section{Acknowledgements}

I wish to thank Miss Margaret Starr, formerly of the InterAmerican University of Puerto Rico, for her assistance in the field work. Milton Sanderson graciously provided specimens from the Illinois Natural History Survey, Urbana. The field work was supported by Evolutionary Biology Training Grant GB3r67 of the National Science Foundation, Prof. Reed C. Rollins, principal investigator, Harvard University.

\section{Literature Cited}

НАтсн, M. H.

1933. Studies on the Leptodiridae (Catopidae) with descriptions of new species. J. New York Ent. Soc. XLI: 187-238.

JEANNEL, R.

1936. Monographie des Catopidae. Mém. Mus. Nat. Hist. Natur., Paris, nouv. sér., 1, $433 \mathrm{pp}$.

Jeannel, $R$, and H. Henrot

1949. Les Coléoptères cavernicoles de la région des Appalaches. Notes Biospeologiques, IV: 9-115.

SZYMCZAKowsKI, W.

1969. Découverte d'un représentant des Ptomaphaginini à Cuba (avec une esquisse de la systématique de la géonémie de cette tribu) (Coleoptera, Catopidae). Acta Zool. Cracoviensia, XIV (4): 87-97. 

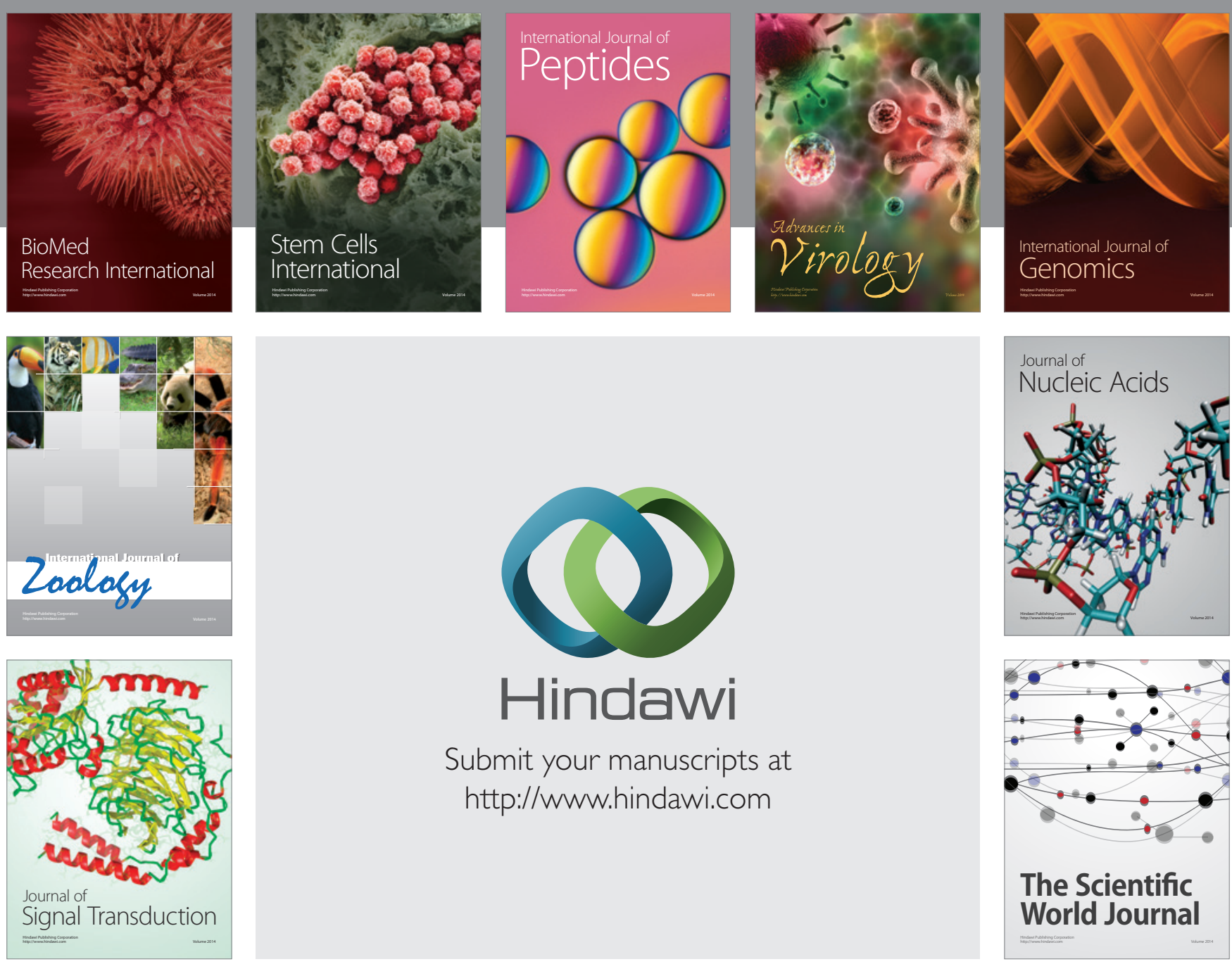

Submit your manuscripts at

http://www.hindawi.com
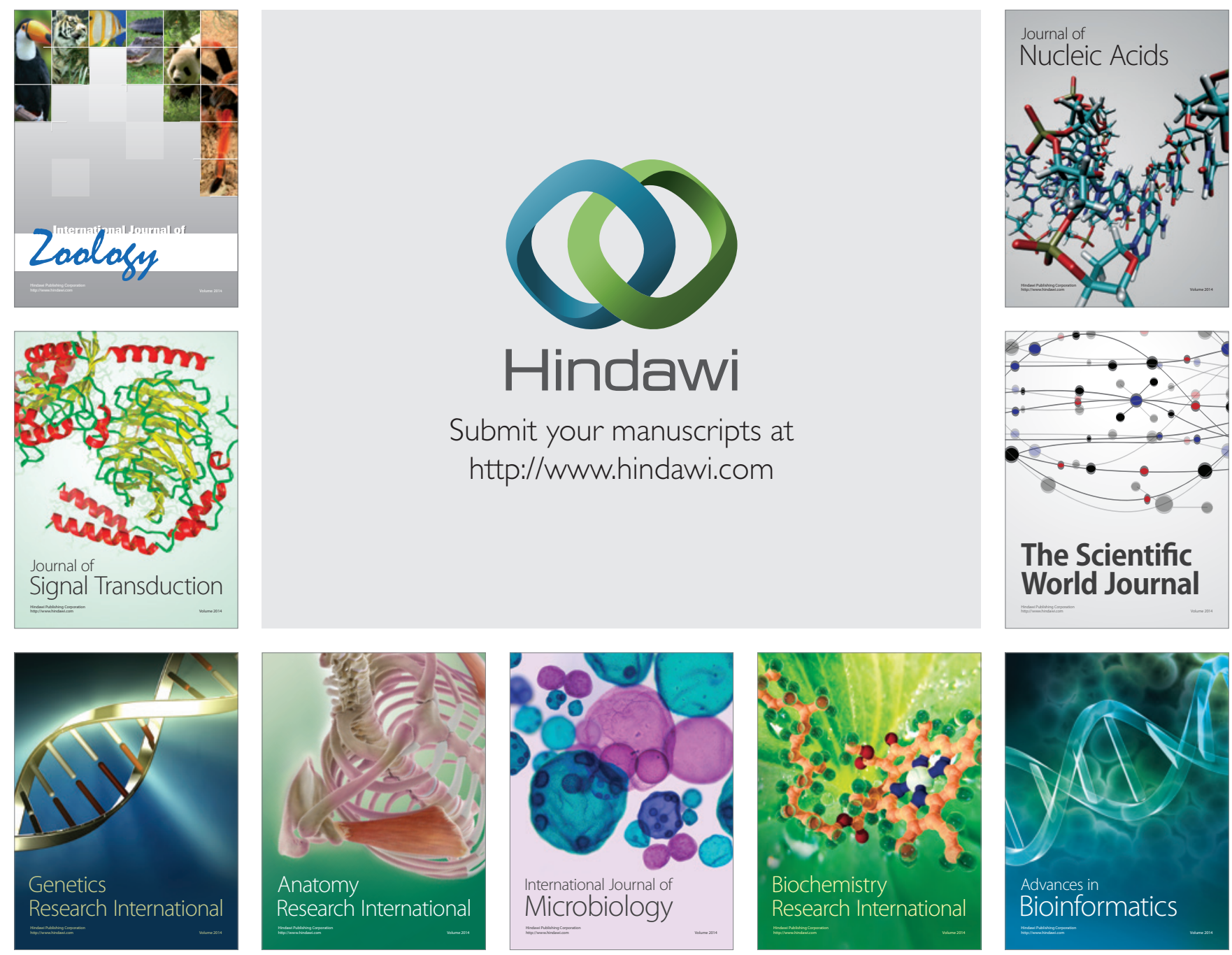

The Scientific World Journal
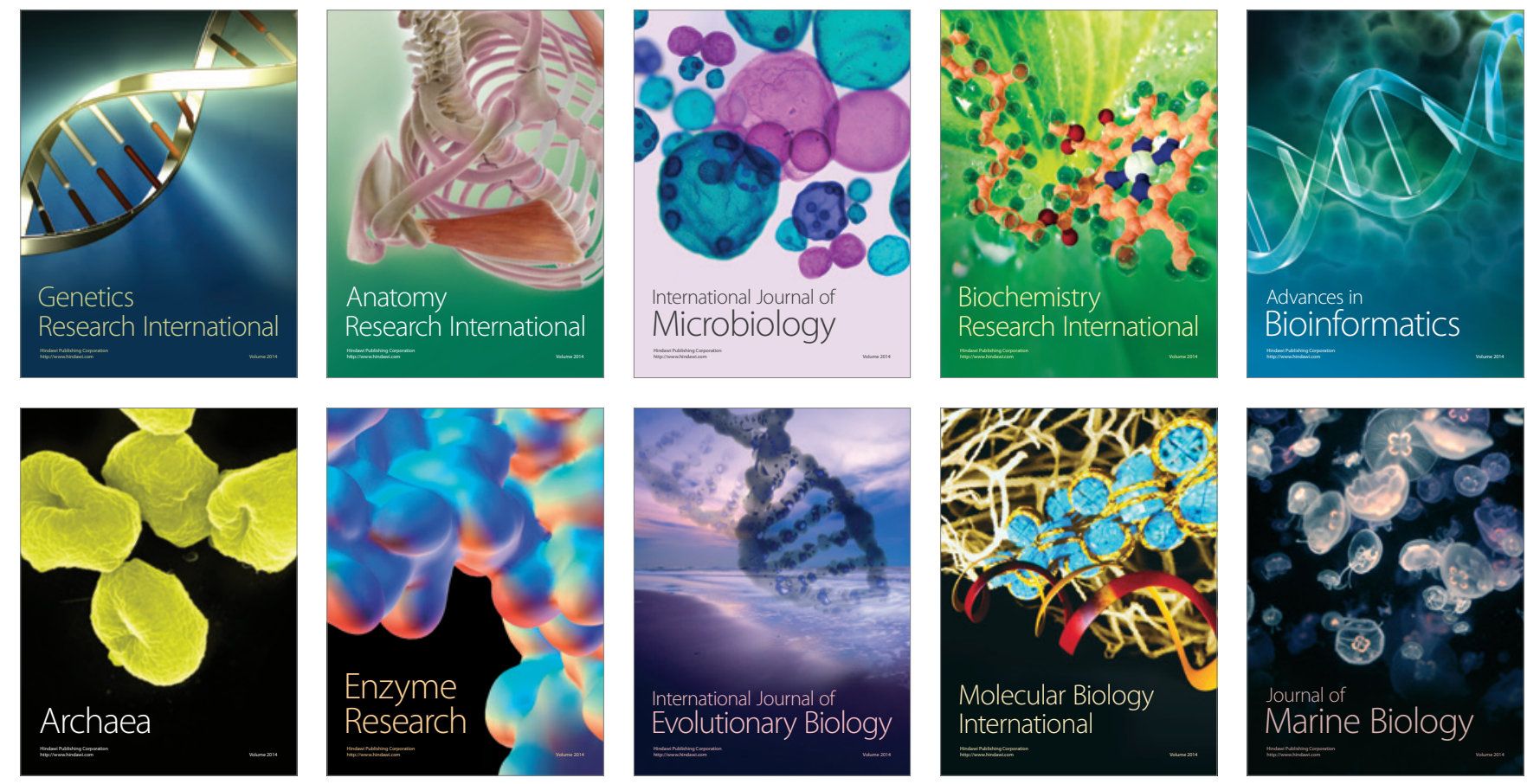